\title{
Risk Factors for Colorectal Cancer in Korea: A Population- Based Retrospective Cohort Study
}

\author{
Soomin $\mathrm{Nam}^{1}$, Yoon Jung Choi ${ }^{2}$, Dong Wook Kim${ }^{3}$ Eun-Cheol Park ${ }^{4}$, Jung-Gu Kang ${ }^{1}$ \\ Departments of ${ }^{1}$ Surgery and ${ }^{2}$ Pathology, National Health Insurance Service Ilsan Hospital, Goyang; ${ }^{3}$ Big Data Department, National Health \\ Insurance Service, Goyang; ${ }^{4}$ Department of Preventive Medicine \& Institute of Health Services Research, Yonsei University College of \\ Medicine, Seoul, Korea
}

Purpose: The incidence of colorectal cancer in Korea has recently increased, making it the second most common cancer in men and the third most common cancer in women. Risk factors for colorectal cancer have been studied worldwide, but risk factors specific for the Korean population have not been established. In this study, we investigated incidence trends and risk factors of colorectal cancer in Korea.

Methods: A total of 8,846,749 subjects were included. Colorectal cancer incidence was investigated using Korea National Health Insurance Service claim data from 2004 to 2014. Colorectal cancer diagnoses were obtained by evaluating colorectal cancer diagnostic codes and the cancer registry for cost sharing. Risk factor identification for colorectal cancer was obtained from National Health Examination data from 2004 to 2005. Cox proportional hazard model statistical analysis was used to determine risk factors of colorectal cancer.

Results: The incidence of colorectal cancer gradually increased from 2006 to 2014 (from 45.4/100,000 to 54.5/100,000). There was a predominance among men (1.47:1), but incidence trends were similar in both sexes. Old age, high body mass index, and no history of colonoscopy were identified as risk factors in both sexes. High fasting blood glucose, familial history of cancer, frequent alcohol intake, and current smoker were identified as risk factors, especially in men.

Conclusion: The incidence of colorectal cancer has been increasing in Korea. Colonoscopy screening was a protective factor for colorectal cancer, and active use of colonoscopy may reduce incidence. Early diagnosis and care are important, particularly for the high-risk group.

Keywords: Colorectal neoplasms; Incidence; Risk factors; Population Characteristics

\section{INTRODUCTION}

Colorectal cancer is the third most common malignancy worldwide and, after skin cancer, the second most common malignancy in most western countries $[1,2]$. In the United States, there are 141,220 new cases and 49,380 deaths annually due to colorectal

Received: September 16, 2019 - Accepted: October 21, 2019

Correspondence to: Jung Gu Kang, M.D.

Department of Surgery, National Health Insurance Service Ilsan Hospital, 100 Ilsan-ro, Ilsandong-gu, Goyang 10444, Korea

Tel: +82-31-900-3566, Fax: +82-31-900-0343

E-mail: kangski@nhimc.or.kr

ORCID code: https://orcid.org/0000-0003-1282-5889

(C) 2019 The Korean Society of Coloproctology

This is an open-access article distributed under the terms of the Creative Commons Attribution NonCommercial License (http://creativecommons.org/licenses/by-nc/4.0) which permits unrestricted noncommercial use, distribution, and reproduction in any medium, provided the original work is properly cited. cancer [3]. The incidence has recently increased in some Asian countries, including Korea. Colorectal cancer has become the second leading cancer in men and the third most frequent cancer in women in Korea [4].

Because of the high and increasing incidence, research has been conducted on colorectal cancer risk factors. Colorectal cancer is associated with dietary factors. Red meat and processed meat diets are known to increase the incidence of colorectal cancer, and dietary fiber intake reduces the risk of colorectal cancer [5]. Smoking is also associated with risk of colorectal cancer [6]. Medical conditions including obesity and diabetes are known risk factors of colorectal cancer [7]. Most studies on colorectal cancer risk factors have been performed in the United States and Europe, and risk factors for colorectal cancer may not be the same in Korea because of differences in race, region, and economic level. Azeem et al. [8] reported that spicy foods and tapioca increase colorectal 
cancer in the Asian population. In India, studies have shown that spicy foods, low-calorie meals, and alcohol consumption may increase the incidence and severity of colorectal cancer [9].

The fecal occult blood test (FOBT) is widely used to screen for colorectal cancer. FOBT use is associated with reduced colorectal cancer mortality [10]. However, the FOBT has relatively low specificity and sensitivity for colorectal neoplasms and cancer [11]. In addition, the positive predictive value of FOBT is relatively low $(3 \%-10 \%)$ [12]. Colonoscopy screening during health examination reduces both the incidence and mortality of colorectal cancer [13]. Distal colon flexible sigmoidoscopy also reduces the mortality of colorectal cancer [14]. Colonoscopy can be performed in conjunction with polypectomy, which is also associated with reduced mortality [15]. However, due to economic reasons and bowel preparation difficulties, routine colonoscopy is difficult to execute as a mass screening tool [16].

The general risk factors of colorectal cancer have been studied worldwide, but specific risk factors for the Korean population have not been researched. In this study, we investigate incidence trends and risk factors of colorectal cancer in Korea.

\section{METHODS}

\section{Database}

The universal health insurance system for all citizens in Korea began in 1977, and the universal health care system was introduced in 1989. Everyone born in Korea is given a unique social security number, and almost all medical records are also registered in the National Health Insurance Service (NHIS) system. Data registered in the NHIS system include patient sociodemographic information, detailed billing details, prescription drug type and dosage, hospital information, and information obtained from periodic inspections during health examination. The inspections consist mainly of questions about lifestyle and results of basic diagnostic tests. All diseases are coded according to the Korean Classification of Disease (KCD), which is similar to the International Classification of Disease, 10th Revision. Many studies have been conducted using the KCD. This study was reviewed and approved by the Institutional Review Board (IRB) of National Health Insurance Service Ilsan Hospital (IRB No. 2017-01-021001), and a waiver of informed consent was granted for data collection from existing medical records of patients.

\section{Study design and participants}

Claims data from the NHIS database from January 1, 2004, to December 31, 2014 were used. For a diagnosis of colorectal cancer, 2 criteria had to be fulfilled. First, the person had to have a KCD diagnostic code of $\mathrm{C} 18, \mathrm{C} 19$, or $\mathrm{C} 20$; second, the person had to meet the exception rule for cost sharing (V193). The cost sharing code is a disease classification code with high accuracy because it requires registration by the national cancer management project. To determine colorectal cancer risk factors, a cohort dataset was constructed. A total of 21,313,265 people had national health screening examinations from January 1, 2004 to December 31,2005 . Of these, $10,783,876$ persons were selected as subjects by removing duplicates based on 2004 examiners. Patients with newly diagnosed cancer (codes C00-C97 by KCD) from January 1, 2004 to December 31, 2005 were excluded. Since people with Korean Medical Care (medical insurance system for low income persons) have no or low income and are susceptible to many diseases, they were excluded from this study. To eliminate measurement and observation errors, subjects with health examination data outliers were excluded. These outliers are described in the supplement, and the detailed flow chart for analysis is shown in Fig. 1.

\section{Statistical analysis}

Data are expressed in the form of frequency (\%), and chi-square tests were performed to determine statistical significance. Most variables were changed to categorical data by setting continuous data intervals. The criteria for separating categories were not specific, but the criteria did not violate data uniformity. Based on previous studies, most results were reported according to sex. Cox proportional hazard model analysis was used to determine the risk factors of colorectal cancer. Results were expressed as hazard ratio (HR) and 95\% confidence interval (CI). The basic assumption of the Cox model was confirmed by $\log (-\log )$ curves. First, significant variables were identified by univariate analysis. Multi-

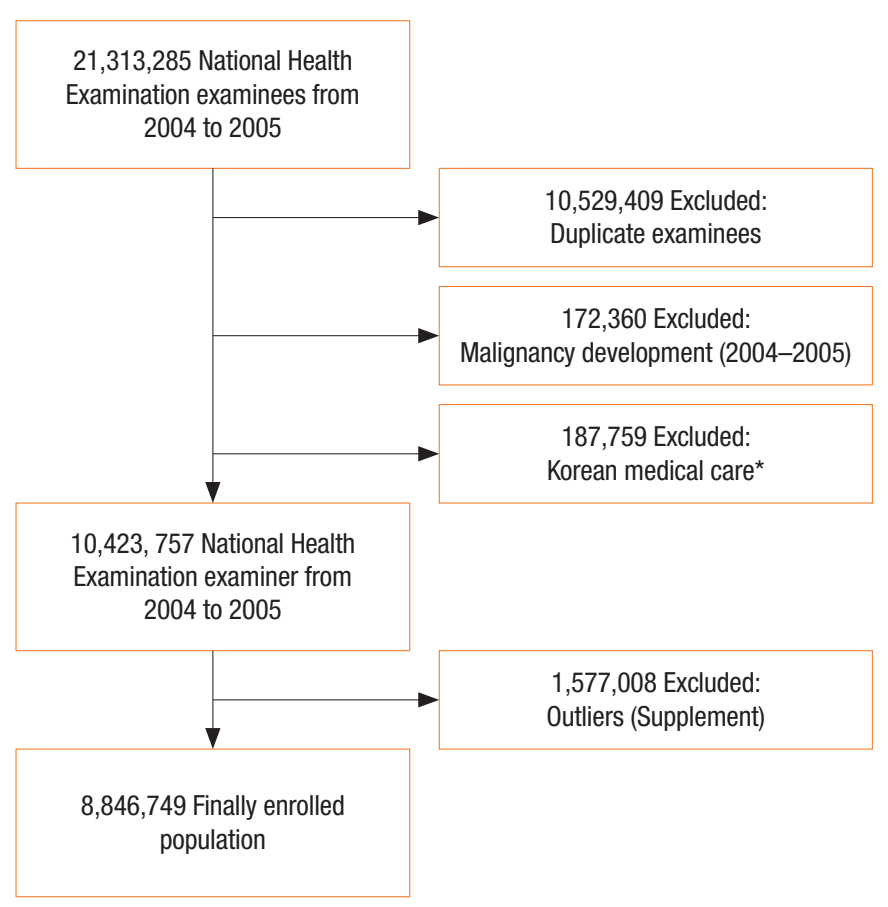

Fig. 1. Flow chart of subjects included in analysis of colorectal cancer risk factors. ${ }^{\star}$ Korean medical care: Special medical insurance system for the low-income population. 
variate analysis was performed using the result of univariate analysis and correcting for necessary variables. Statistical analysis was performed using SAS ver. 9.4 (SAS Institute Inc., Cary, NC, USA). P-value $<0.05$ was considered statistically significant.

\section{RESULTS}

To estimate the incidence of colorectal cancer among Koreans, the number of newly diagnosed colon cancer cases was counted every year from 2006 to 2014, and the incidence and prevalence per 100,000 people was calculated. Because of differences in incidence, occurrence and incidence data were presented according to age and sex. Overall, there is a pattern of increasing incidence until 2012. The incidence per 100,000 people in 2006 was $45.4 / 100,000$, and this incidence increased to $54.4 / 100,000$ in 2014. A similar pattern was observed when incidence was analyzed by sex (Table 1 ).

Men had higher colorectal cancer incidence than women. The peak incidence occurred in 2012 in both sexes, with incidence of $67.9 / 100,000$ in men and 45.3/100,000 in women (Table 1). In 2008 , the male age group with highest incidence was the 70 - to 79 -year-old age group (372.7/100,000); after 2009 this changed to the over 80 -year-old age group $(401.7 / 100,000)$. In those under 40-year-old age, incidence was 2.9/100,000 in 2006 and 3.2/ 100,000 in 2014. In those aged 40-49, incidence was $31.7 / 100,000$ in 2006 and 29.1/100,000 in 2014, reflecting a fairly high incidence of colorectal cancer in people below 50-year-old age. In 2014 , the incidence was $212.0 / 100,000$ for men in their $60 \mathrm{~s}$, $347.4 / 1000,000$ for men in their 70s, and 412.2/100,000 for men in the over 80 -year-old age group. These data indicate a high incidence of colorectal cancer in men over 60-year-old age. In women, the highest incidence was observed in women in their 70 s in $2007(183.2 / 100,000)$ and in those over 80-year-old age beginning in $2008(189.0 / 100,000)$. In the group under 40 -year-old age, incidence was 2.7/100,000 in 2006 and 2.9/100,000 in 2014.
In women in their 40s, incidence was 26.0/100,000 in 2006 and $23.0 / 100,000$ in 2014, also reflecting a high incidence of colorectal cancer in women below 50-year-old age. In 2014, the incidence was $101.9 / 100,000$ for women in their $60 \mathrm{~s}, 181.3 / 1000,000$ for women in their 70s, and 220.9/100,000 for women in the over 80 -year-old age group, indicating high incidence in these age groups similar to men. In both sexes, incidence in the 70- to 79-year-old age groups showed a decreasing trend, while incidence in over 80 -year-old age groups showed substantial increases.

Risk factors for colorectal cancer were analyzed by sex. First, the results in men are as follows. Risk of colorectal cancer increased with age, and HR was highest in the over 80 -year-old age group (HR, 19.190; $\mathrm{P}<0.001)$. Increased age was a risk factor for colorectal cancer in men (Table 2). Risk of colorectal cancer increased with increasing BMI, and BMI over $23 \mathrm{~kg} / \mathrm{m}^{2}$ was revealed to be a risk factor of colorectal cancer $\left(23-25 \mathrm{~kg} / \mathrm{m}^{2}: \mathrm{HR}\right.$, $\left.1.111 ; \mathrm{P}=0.0272 ; \geq 25 \mathrm{~kg} / \mathrm{m}^{2}: \mathrm{HR}, 1.254 ; \mathrm{P}<0.001\right)$. The risk of colorectal cancer was higher when fasting blood glucose was higher than $126 \mathrm{mg} / \mathrm{dL}(\mathrm{HR}, 1.217 ; \mathrm{P}<0.001)$. The risk of total cholesterol level was analyzed among 3 groups of less than 200 $\mathrm{mg} / \mathrm{dL}, 200-240 \mathrm{mg} / \mathrm{dL}$, and more than $240 \mathrm{mg} / \mathrm{dL}$. There were no significant relationships among the 3 groups and risk of colorectal cancer. Family history of diabetes mellitus (DM) and malignancy was also analyzed. Family history of DM showed no significant association with risk of colorectal cancer, but family history of malignancy showed increased risk of colorectal cancer (HR, 1.163; P < 0.001). Alcohol consumption was analyzed based on 5 groups: none, 2-3 times a month, 1-2 times a week, 3-4 times a week, and almost every day. The results showed that risk increased with more frequent alcohol consumption. Smoking status was analyzed by non-smoker, ex-smoker, and current smoker. Current smokers showed significantly higher risk of colorectal cancer than non-smokers and ex-smokers (HR, 1.093; $\mathrm{P}=0.021)$. Colonoscopy during health examinations reduced the risk of

Table 1. Prevalence and incidence of colorectal cancer

\begin{tabular}{llll}
\hline Year & \multicolumn{1}{c}{ Overall } & Men & Women \\
\hline 2005 & $39,000(79.3) /-$ & $22,752(92.1) /-$ & $16,248(66.5) /-$ \\
2006 & $67,336(136.8) / 22,332(45.4)$ & $39,114(158.1) / 13,038(52.7)$ & $28,222(115.2) / 9,294(37.9)$ \\
2007 & $85,816(172.8) / 22,225(44.7)$ & $49,979(200.4) / 13,086(52.5)$ & $35,837(144.9) / 9,139(37.0)$ \\
2008 & $103,112(206.2) / 22,980(46.0)$ & $60,308(240.2) / 13,674(54.5)$ & $42,804(171.9) / 9,306(37.4)$ \\
2009 & $121,765(242.1) / 25,200(50.1)$ & $71,537(283.4) / 15,132(59.9)$ & $50,228(200.5) / 10,068(40.2)$ \\
2010 & $140,895(278.6) / 26,421(52.2)$ & $83,138(327.6) / 15,836(62.4)$ & $57,757(229.2) / 10,585(42.0)$ \\
2011 & $160,642(315.5) / 28,326(55.6)$ & $95,250(373.0) / 17,165(67.2)$ & $65,392(257.7) / 11,161(44.0)$ \\
2012 & $180,708(353.2) / 28,973(56.6)$ & $107,349(418.6) / 17,413(67.9)$ & $73,359(287.4) / 11,560(45.3)$ \\
2013 & $199,693(388.1) / 28,628(55.6)$ & $118,769(460.7) / 17,226(66.8)$ & $80,924(315.3) / 11,402(44.4)$ \\
2014 & $217,955(421.1) / 28,161(54.4)$ & $129,636(499.9) / 16,804(64.8)$ & $88,319(342.0) / 11,357(44.0)$ \\
\hline
\end{tabular}

Values are presented as prevalence (per 100,000)/incidence (per 100,000). 
Annals of Risk Factors for Colorectal Cancer in Korea: A Population-Based Retrospective Cohort Study

Coloproctology Soomin Nam, et al.

Table 2. Incidence and risk factors of colorectal cancer in men $(n=5,105,889)$

\begin{tabular}{|c|c|c|c|c|c|}
\hline \multirow{2}{*}{ Variable } & \multirow{2}{*}{ Total } & \multicolumn{2}{|c|}{ Colorectal cancer } & \multirow{2}{*}{$\mathrm{HR}(95 \% \mathrm{Cl})$} & \multirow{2}{*}{ P-value } \\
\hline & & Yes & No & & \\
\hline \multicolumn{6}{|l|}{ Age (yr) } \\
\hline$<40$ & $1,718,961(33.7)$ & $4,024(6.2)$ & $1,714,937(34.0)$ & 1.000 & \\
\hline $40-49$ & $1,550,303(30.4)$ & $12,122(18.5)$ & $1,538,181(30.5)$ & 2.685 (2.331-3.093) & $<0.001$ \\
\hline $50-59$ & $979,572(19.2)$ & 19,435 (29.7) & $960,137(19.0)$ & 6.529 (5.689-7.492) & $<0.001$ \\
\hline $60-69$ & $608,683(11.9)$ & $20,637(31.6)$ & $588,046(11.7)$ & $13.376(11.636-15.377)$ & $<0.001$ \\
\hline $70-79$ & $216,795(4.2)$ & $8,314(12.7)$ & $208,481(4.1)$ & $19.177(16.334-22.513)$ & $<0.001$ \\
\hline$\geq 80$ & $31,575(0.6)$ & $817(1.3)$ & $30,758(0.6)$ & $19.190(13.288-27.712)$ & $<0.001$ \\
\hline \multicolumn{6}{|c|}{ Body mass index $\left(\mathrm{kg} / \mathrm{m}^{2}\right)$} \\
\hline$<18.5$ & $107,303(2.1)$ & $1,385(2.1)$ & $105,918(2.1)$ & 1.000 & \\
\hline $18.5-23$ & $1,628,404(31.9)$ & $19,892(30.4)$ & $1,608,512(31.9)$ & $1.071(0.981-1.170)$ & 0.125 \\
\hline $23-25$ & $1,428,447(28)$ & $18,725(28.7)$ & $1,409,722(28)$ & $1.111(1.012-1.220)$ & 0.027 \\
\hline$>25$ & $1,941,735$ (38) & 25,347 (38.8) & 1,916,388 (38) & $1.254(1.141-1.377)$ & $<0.001$ \\
\hline \multicolumn{6}{|c|}{ Fasting blood glucose (mg/dL) } \\
\hline$<126$ & $4,759,751(93.2)$ & $58,073(88.9)$ & $4,701,678$ (93.3) & 1.000 & \\
\hline$\geq 126$ & $346,138(6.8)$ & $7,276(11.1)$ & $338,862(6.7)$ & 1.217 (1.092-1.356) & $<0.001$ \\
\hline \multicolumn{6}{|c|}{ Total cholesterol (mg/dL) } \\
\hline$<200$ & $3,038,715(59.5)$ & $37,931(58.0)$ & $3,000,784(59.5)$ & 1.000 & \\
\hline $200-240$ & $1,527,822(29.9)$ & $20,101(30.8)$ & $1,507,721(29.9)$ & $0.956(0.891-1.025)$ & 0.201 \\
\hline$>240$ & $539,352(10.6)$ & $7,317(11.2)$ & $532,035(10.6)$ & $1.018(0.920-1.126)$ & 0.734 \\
\hline \multicolumn{6}{|c|}{ Family history of DM } \\
\hline No & $4,371,505(92.8)$ & $56,628(94.4)$ & $4,314,877(92.8)$ & 1.000 & \\
\hline Yes & $338,772(7.2)$ & $3,378(5.6)$ & $335,394(7.2)$ & $0.910(0.794-1.042)$ & 0.173 \\
\hline \multicolumn{6}{|c|}{ Family history of malignancy } \\
\hline No & $4,155,911(87.9)$ & $53,136(88.2)$ & $4,102,775(87.9)$ & 1.000 & \\
\hline Yes & $569,367(12.1)$ & $7,099(11.8)$ & $562,268(12.1)$ & 1.163 (1.066-1.269) & $<0.001$ \\
\hline \multicolumn{6}{|c|}{ Alcohol consumption } \\
\hline Never & $1,694,201(33.2)$ & $23,087(35.8)$ & $1,671,114(33.6)$ & 1.000 & \\
\hline 2-3 times/mo & $1,099,887(21.5)$ & $10,481(16.3)$ & $1,089,406(21.9)$ & $1.105(1.007-1.212)$ & 0.035 \\
\hline 1-2 times/wk & $159,186(3.1)$ & $16,022(24.8)$ & $1,431,649(28.8)$ & $1.217(1.118-1.325)$ & $<0.001$ \\
\hline 3-4 times/wk & $538,531(10.5)$ & $8,412(13.0)$ & $530,119(10.7)$ & $1.360(1.223-1.511)$ & $<0.001$ \\
\hline Everyday & $258,287(5.1)$ & $6,474(10.0)$ & $251,813(5.1)$ & 1.490 (1.320-1.682) & $<0.001$ \\
\hline \multicolumn{6}{|l|}{ Smoking } \\
\hline None & $2,072,613(40.6)$ & $29,168(45.4)$ & $2,043,445(41.2)$ & 1.000 & \\
\hline Ex-smoker & $823,774(16.1)$ & $11,488(17.9)$ & $812,286(16.4)$ & 1.079 (0.994-1.173) & 0.070 \\
\hline Current smoker & $2,129,870(41.7)$ & 23,637 (36.8) & $2,106,233(42.4)$ & $1.093(1.013-1.180)$ & 0.022 \\
\hline \multicolumn{6}{|c|}{ History of colonoscopy } \\
\hline No & 194,655 (39.2) & $2,169(47.9)$ & 192,486 (39.1) & 1.000 & \\
\hline Yes & $301,849(60.8)$ & $2,362(52.1)$ & 299,487 (60.9) & $0.501(0.470-0.533)$ & $<0.001$ \\
\hline
\end{tabular}

Values are presented as number (\%) unless otherwise indicated.

$\mathrm{HR}$, hazard ratio; $\mathrm{Cl}$, confidence interval; DM, diabetes mellitus. 
Table 3. Incidence and risk factors of colorectal cancer in women $(n=3,654,706)$

\begin{tabular}{|c|c|c|c|c|c|}
\hline \multirow{2}{*}{ Variable } & \multirow{2}{*}{ Total } & \multicolumn{2}{|c|}{ Colorectal cancer } & \multirow{2}{*}{$\mathrm{HR}(95 \% \mathrm{Cl})$} & \multirow{2}{*}{ P-value } \\
\hline & & Yes & No & & \\
\hline \multicolumn{6}{|l|}{ Age (yr) } \\
\hline$<40$ & $565,986(15.5)$ & $1,743(4.7)$ & $564,243(15.6)$ & 1.000 & \\
\hline $40-49$ & 1,192,095 (32.6) & $7,619(20.4)$ & $1,184,476(32.7)$ & $2.011(1.624-2.490)$ & $<0.001$ \\
\hline $50-59$ & $925,748(25.3)$ & $10,032(26.8)$ & $915,716(25.3)$ & 2.987 (2.407-3.707) & $<0.001$ \\
\hline $60-69$ & $657,412(18.0)$ & $11,496(30.7)$ & $645,916(17.9)$ & $5.207(4.184-6.479)$ & $<0.001$ \\
\hline $70-79$ & $273,253(7.5)$ & $5,831(15.6)$ & $267,422(7.4)$ & $8.186(6.452-10.386)$ & $<0.001$ \\
\hline$\geq 80$ & $40,212(1.1)$ & $669(1.8)$ & $39,543(1.1)$ & 9.72 (5.929-15.934) & $<0.001$ \\
\hline \multicolumn{6}{|c|}{ Body mass index $\left(\mathrm{kg} / \mathrm{m}^{2}\right)$} \\
\hline$<18.5$ & $127,463(3.5)$ & $842(2.3)$ & $126,621(3.5)$ & 1.000 & \\
\hline $18.5-23$ & $1,519,420(41.6)$ & $12,711(34.0)$ & $1,506,709(41.7)$ & $1.110(0.975-1.265)$ & 0.116 \\
\hline $23-25$ & $892,897(24.4)$ & $9,479(25.4)$ & $883,418(24.4)$ & $1.221(1.073-1.388)$ & 0.002 \\
\hline$>25$ & $1,114,926(30.5)$ & $14,358(38.4)$ & $1,100,568(30.4)$ & $1.250(1.103-1.417)$ & 0.001 \\
\hline \multicolumn{6}{|c|}{ Fasting blood glucose (mg/dL) } \\
\hline$<126$ & $347,2851(95.0)$ & $34,541(92.4)$ & $3,438,310(95.1)$ & 1.000 & \\
\hline$\geq 126$ & $181,855(5.0)$ & $2,849(7.6)$ & $179,006(4.9)$ & $1.183(0.997-1.404)$ & 0.054 \\
\hline \multicolumn{6}{|c|}{ Total cholesterol (mg/dL) } \\
\hline$<200$ & 2,093,347 (57.3) & $18,267(48.9)$ & $2,075,080(57.4)$ & 1.000 & \\
\hline $200-240$ & $1,091,988(29.9)$ & $12,699(34.0)$ & $1,079,289(29.8)$ & $1.067(0.974-1.170)$ & 0.165 \\
\hline$>240$ & $469,371(12.8)$ & $6,424(17.2)$ & $462,947(12.8)$ & 1.059 (0.939-1.195) & 0.346 \\
\hline \multicolumn{6}{|c|}{ Family history of DM } \\
\hline No & $3,113,793(92.2)$ & $32,115(93.1)$ & $3,081,678(92.2)$ & 1.000 & \\
\hline Yes & $262,790(7.8)$ & $2,390(6.9)$ & $260,400(7.8)$ & $1.115(0.961-1.294)$ & 0.152 \\
\hline \multicolumn{6}{|c|}{ Family history of malignancy } \\
\hline No & $2,921,230(86.2)$ & $29,605(85.4)$ & $2,891,625(86.2)$ & 1.000 & \\
\hline Yes & 469,388 (13.8) & $5,069(14.6)$ & $464,319(13.8)$ & $1.103(0.990-1.230)$ & 0.076 \\
\hline \multicolumn{6}{|c|}{ Alcohol consumption } \\
\hline Never & $2,839,365(77.7)$ & 30,648 (83.8) & $2,808,717$ (79.2) & 1.000 & \\
\hline 2-3 times/mo & $457,398(12.5)$ & $3,513(9.6)$ & $453,885(12.8)$ & $0.973(0.844-1.122)$ & 0.705 \\
\hline 1-2 times/wk & $222,337(6.1)$ & $1,752(4.8)$ & $220,585(6.2)$ & $0.925(0.758-1.129)$ & 0.443 \\
\hline 3-4 times/wk & $39,489(1.1)$ & $387(1.1)$ & $39,102(1.1)$ & $1.111(0.740-1.668)$ & 0.612 \\
\hline Everyday & $22,483(0.6)$ & $269(0.7)$ & $22,214(0.6)$ & $1.494(0.959-2.327)$ & 0.076 \\
\hline \multicolumn{6}{|l|}{ Smoking } \\
\hline None & $3,419,049(93.6)$ & 34,777 (95.9) & $3,384,272(96.4)$ & 1.000 & \\
\hline Ex-smoker & $39,908(1.1)$ & $434(1.2)$ & $39,474(1.1)$ & 1.293 (0.919-1.821) & 0.140 \\
\hline Current smoker & $88,959(2.4)$ & $1,057(2.9)$ & $87,902(2.5)$ & 0.988 (0.743-1.313) & 0.934 \\
\hline \multicolumn{6}{|c|}{ History of colonoscopy } \\
\hline No & $117,231(34.4)$ & $1,097(41.4)$ & 116,134 (34.3) & 1.000 & \\
\hline Yes & $223,914(65.6)$ & $1,555(58.6)$ & $222,359(65.7)$ & $0.609(0.560-0.663)$ & $<0.001$ \\
\hline
\end{tabular}

Values are presented as number (\%) unless otherwise indicated. $\mathrm{HR}$, hazard ratio; Cl, confidence interval; DM, diabetes mellitus. 
colorectal cancer (HR, 0.501; $\mathrm{P}<0.001)$ (Table 2).

In women, risk increased with age, and the risk was highest in patients over 80 years $(\mathrm{HR}, 9.720 ; \mathrm{P}<0.001)$ (Table 3). Risk increased with increasing BMI, and BMI over $23 \mathrm{~kg} / \mathrm{m}^{2}$ was revealed as a risk factor of colorectal cancer $\left(23-25 \mathrm{~kg} / \mathrm{m}^{2}\right.$ : HR, $\left.1.221 ; \mathrm{P}=0.0024 ; \geq 25 \mathrm{~kg} / \mathrm{m}^{2}: \mathrm{HR}, 1.250 ; \mathrm{P}=0.0005\right)$. The level of fasting blood glucose and total cholesterol were not significant risk factors for colorectal cancer. DM and malignancy showed no significant relationship with increased colorectal cancer risk in women. Frequency of alcohol consumption and smoking were not found to be risk factors in women. Colonoscopy also reduced the risk of colorectal cancer in women (HR, 0.609; P < 0.001) (Table 3).

Risk factors were also analyzed according to location of colorectal cancer. In men, right colon cancer had the greatest increase in risk with increasing age, and rectal cancer had the lowest increase (Table 4). Frequent alcohol consumption was a risk factor, but was not a risk factor in left colon cancer (Table 4). In women, total cholesterol level was not a risk factor of colorectal cancer overall, but was a risk factor in left colon cancer (Table 5).

\section{DISCUSSION}

This study showed a trend of increasing colorectal cancer in Korea. The incidence has increased from 45.4/100,000 in 2012 to $54.4 / 100,000$ in 2014. Analysis of old Korean data shows that incidence in men was 1999 in 27.0/100,000, which increased to 50.2 in 2009. In women, the incidence in 1999 was $17.2 / 100,000$, which increased to $26.9 / 100,000$ in 2009 [17]. In our data, the incidence in 2014 was 64.8/100,000 in men and 44.0/100,000 in women. This demonstrates that the incidence of colorectal cancer in Korea has been dramatically increasing. Compared to other countries, the incidence of colorectal cancer in Korea is high. In 2012 , the incidence in men was highest in Korea $(50.0 / 100,000)$, followed by New Zealand $(49.1 / 100,000)$. Korea had the third highest total incidence including men and women the world (Koreans, 37.3/100,000) after New Zealand $(43.5 / 100,000)$ and the Netherlands $(38.9 / 100,000)$ [17]. The United States used to have the highest incidence in the world, but it has been decreasing since the 1990s [18]. Compared to Singapore, the incidence is very high in Korea. The age-standardized rate in 2008-2012 was 20.5/100,000 in Singapore [19]. Meat consumption per person in Korea was $41.0 \mathrm{~kg}$ in 2006 and $51.9 \mathrm{~kg}$ in 2014 [20]. The increase of meat consumption may be related to the increased incidence of colorectal cancer. The incidence of colorectal cancer in Korea has been increasing dramatically, with a plateau in incidence since 2012. The cause of the plateau is unknown, but may be due to the increased interest in health care, healthy lifestyle, and eating habits. Since 2009, colonoscopy has been performed for those who are FOBT positive through National Health Examinations. An increase in health examinations and colonoscopies may have slowed down the increasing trend. Additional research is needed to find the exact cause.

Unlike other malignancies, the genetic and molecular biological pathogenesis of colorectal cancer has been extensively studied. Transition from adenoma to carcinoma describes the natural history of colon cancer development. In addition, the development of colorectal cancer due to microorganisms and intestinal factors also has been well-studied [21]. The functions of the large intestine are to deliver food from the small intestine to the rectum and to absorb water and electrolytes. Intestinal microorganisms metabolize the remaining food and digestive fluids. Cells in the colon crypts are active and proliferative, requiring nutrients. The proliferative process is affected by dietary changes [22]. Genetic changes that develop during dietary changes accumulate and lead to genomic instability. These changes result in colorectal cancer development [23]. By-products of protein digestion are fermented by colonic bacteria to produce ammonia, phenol, and hydrogen sulfide. Nitrate and nitrite are introduced into the colonic mucosa when processed meat is ingested. These substances cause inflammation and damage to the colon mucosa [24].

To ascertain the risk factors of colorectal cancer, variables included in the National Health Examination data and reported as risk factors in other studies were analyzed. In our study, increased age and BMI were revealed as risk factors in both men and women. Colonoscopy performance as part of health examinations was a protective factor for colorectal cancer. Especially in men, high fasting blood glucose and family history of malignancy were risk factors. Frequent alcohol consumption and current smoking were also risk factors for colorectal cancer in men. The relationship between increased age and colorectal cancer has been well-studied [25]. Our data also demonstrated that increased age is a risk factor for both sexes. Obesity is also a risk factor for colorectal cancer [26, 27]. Shin et al. [28] reported that high BMI is a risk factor for colorectal cancer in men, and low BMI is a protective factor in women.

The relationship of colorectal cancer with family history has been well-studied. Familial history of colorectal cancer increases the risk of colorectal cancer [29]. Familial history of other malignancies, such as gastric cancer and prostate cancer, also increases the risk of colorectal cancer [30,31]. In this study, family history of DM and any malignancy was investigated, and familial history of DM-related malignancy was a risk factor in men. Disease presence is a risk factor for colorectal cancer. A personal history of DM is well known to increase the risk of colorectal cancer [7]. In our study, serum cholesterol level was not a significant risk factor for colorectal cancer, and high serum glucose level was a risk factor only in men.

Dietary habits are known to be important risk factors. Ingestion of red meat and processed meat such as bacon, ham, or sausage are well known risk factors [32]. Eating fried meat increases the risk of colorectal cancer [33]. Every 30-g increase of daily red meat and processed meat consumption increases colorectal cancer risk by $10 \%$ [34]. Increased total meat intake increases the risk 
Table 4. Risk factors of colorectal cancer by location in men

\begin{tabular}{|c|c|c|c|c|c|}
\hline Variable & All & Colon & Rectum & Right colon & Left colon \\
\hline \multicolumn{6}{|l|}{ Age (yr) } \\
\hline$<40$ & 1.000 & 1.000 & 1.000 & 1.000 & 1.000 \\
\hline $50-59$ & $6.529(5.689-7.492)^{*}$ & $7.935(6.611-9.524)^{\star}$ & $4.935(3.987-6.109)^{*}$ & $9.66(6.623-14.089)^{\star}$ & $7.164(4.385-11.703)^{\star}$ \\
\hline $60-69$ & $13.376(11.636-15.377)^{*}$ & $17.217(14.327-20.690)^{*}$ & $8.889(7.131-11.081)^{*}$ & $20.668(14.122-30.248)^{\star}$ & $17.226(10.548-28.132)^{\star}$ \\
\hline$\geq 80$ & $19.190(13.288-27.712)^{\star}$ & $24.431(15.624-38.203)^{*}$ & $13.263(6.889-25.534)^{*}$ & $30.096(12.431-72.866)^{\star}$ & $23.129(6.759-79.152)^{\star}$ \\
\hline \multicolumn{6}{|c|}{ Fasting blood glucose (mg/dL) } \\
\hline$<126$ & 1.000 & 1.000 & 1.000 & 1.000 & 1.000 \\
\hline$\geq 126$ & $1.217(1.092-1.356)^{\star}$ & $1.231(1.081-1.401)^{\star}$ & $1.191(0.977-1.452)$ & $1.207(0.927-1.572)$ & $1.512(1.1-2.078)^{\star}$ \\
\hline \multicolumn{6}{|c|}{ Total cholesterol (mg/dL) } \\
\hline \multicolumn{6}{|l|}{ Family history of DM } \\
\hline No & 1.000 & 1.000 & 1.000 & 1.000 & 1.000 \\
\hline Yes & $0.910(0.794-1.042)$ & $0.821(0.691-0.975)^{*}$ & $1.103(0.884-1.376)$ & $0.584(0.388-0.881)^{*}$ & $0.953(0.622-1.458)$ \\
\hline \multicolumn{6}{|c|}{ Family history of malignancy } \\
\hline No & 1.000 & 1.000 & 1.000 & 1.000 & 1.000 \\
\hline Yes & $1.163(1.066-1.269)^{\star}$ & $1.128(1.014-1.254)^{\star}$ & $1.243(1.068-1.447)^{*}$ & $0.989(0.787-1.243)$ & $1.380(1.058-1.801)^{\star}$ \\
\hline \multicolumn{6}{|c|}{ Alcohol consumption } \\
\hline Never & 1.000 & 1.000 & 1.000 & 1.000 & 1.000 \\
\hline Ex-smoker & 1.079 (0.994-1.173) & $1.101(0.997-1.216)$ & $1.033(0.890-1.200)$ & $1.270(1.045-1.544)^{*}$ & $1.198(0.928-1.548)$ \\
\hline Current smoker & $1.093(1.013-1.180)^{*}$ & 1.089 (0.992-1.195) & $1.101(0.963-1.259)$ & $1.091(0.903-1.318)$ & $1.018(0.789-1.312)$ \\
\hline \multicolumn{6}{|c|}{ Experience of colonoscopy } \\
\hline No & 1.000 & 1.000 & 1.000 & 1.000 & 1.000 \\
\hline Yes & $0.501(0.470-0.533)^{*}$ & $0.539(0.500-0.582)^{\star}$ & $0.422(0.377-0.472)^{*}$ & $0.289(0.247-0.338)^{*}$ & $0.593(0.484-0.726)^{*}$ \\
\hline
\end{tabular}

Values are presented as hazard ratio (95\% confidence interval).

$\mathrm{HR}$, hazard ratio; $\mathrm{Cl}$, confidence interval; DM, diabetes mellitus.

${ }^{*} \mathrm{P}<0.05$.

of colorectal cancer by $21 \%-28 \%$ [35]. An experimental study revealed that the fatty acids of animal fat act as a carcinogen in colorectal cancer [36]. Consumption of dietary fiber is a known protective factor for colorectal cancer [37]. As dietary fiber ferments in the large intestine, short chain fatty acids (SCFA), such as butyrate, acetate, and propionate, are produced. SCFA are used as a main energy source for colonic mucosa cells to maintain antiinflammatory functions, preventing development of colorectal cancer [38]. Dietary risks are difficult to research because of difficulties in acquiring detailed data. In this study, acquisition of such data was impossible. The National Health Examination data questionnaire only differentiates among meat-eaters, eaters of both 
Table 5. Risk factors of colorectal cancer by location in women

\begin{tabular}{|c|c|c|c|c|c|}
\hline Variable & All & Colon & Rectum & Right colon & Left colon \\
\hline \multicolumn{6}{|l|}{ Age (yr) } \\
\hline$<40$ & 1.000 & 1.000 & 1.000 & 1.000 & 1.000 \\
\hline $40-49$ & $2.011(1.624-2.490)^{\star}$ & $1.824(1.431-2.325)^{\star}$ & $2.675(1.701-4.207)^{\star}$ & $2.388(1.249-4.565)^{*}$ & $5.024(1.553-16.254)^{*}$ \\
\hline $50-59$ & $2.987(2.407-3.707)^{\star}$ & $2.624(2.052-3.354)^{\star}$ & $4.341(2.756-6.837)^{\star}$ & $4.472(2.341-8.544)^{*}$ & $7.939(2.462-25.603)^{*}$ \\
\hline $60-69$ & $5.207(4.184-6.479)^{\star}$ & $4.565(3.558-5.856)^{\star}$ & $7.642(4.826-12.101)^{*}$ & $7.252(3.748-14.032)^{\star}$ & $23.470(7.327-75.178)^{\star}$ \\
\hline $70-79$ & $8.186(6.452-10.386)^{*}$ & $7.101(5.402-9.335)^{\star}$ & $12.329(7.553-20.125)^{\star}$ & $13.512(6.723-27.157)^{\star}$ & $41.612(12.740-135.913)^{\star}$ \\
\hline$\geq 80$ & $9.720(5.929-15.934)^{*}$ & $6.561(3.383-12.721)^{\star}$ & $20.932(9.533-45.963)^{*}$ & $20.429(6.395-65.260)^{\star}$ & $30.182(4.986-182.694)^{*}$ \\
\hline \multicolumn{6}{|c|}{ Fasting blood glucose (mg/dL) } \\
\hline$<126$ & 1.000 & 1.000 & 1.000 & 1.000 & 1.000 \\
\hline$\geq 126$ & $1.183(0.997-1.404)$ & $1.187(0.970-1.452)$ & $1.176(0.853-1.623)$ & $1.326(0.843-2.088)$ & $1.062(0.654-1.724)$ \\
\hline \multicolumn{6}{|c|}{ Total cholesterol (mg/dL) } \\
\hline$<200$ & 1.000 & 1.000 & 1.000 & 1.000 & 1.000 \\
\hline $200-240$ & $1.067(0.974-1.170)$ & $1.051(0.944-1.171)$ & $1.112(0.933-1.326)$ & $0.979(0.754-1.271)$ & $1.320(1.004-1.735)^{*}$ \\
\hline$>240$ & 1.059 (0.939-1.195) & $1.043(0.905-1.202)$ & $1.105(0.880-1.386)$ & $0.852(0.597-1.217)$ & $1.614(1.172-2.223)^{*}$ \\
\hline \multicolumn{6}{|c|}{ Family history of DM } \\
\hline No & 1.000 & 1.000 & 1.000 & 1.000 & 1.000 \\
\hline Yes & 1.115 (0.961-1.294) & $1.111(0.934-1.321)$ & $1.128(0.844-1.507)$ & $1.371(0.922-2.037)$ & $0.810(0.479-1.370)$ \\
\hline \multicolumn{6}{|c|}{ Family history of malignancy } \\
\hline No & 1.000 & 1.000 & 1.000 & 1.000 & 1.000 \\
\hline Yes & $1.103(0.990-1.230)$ & $1.140(1.006-1.292)^{\star}$ & $1.001(0.805-1.245)$ & $0.870(0.619-1.223)$ & $1.000(0.715-1.398)$ \\
\hline \multicolumn{6}{|c|}{ Alcohol consumption } \\
\hline Never & 1.000 & 1.000 & 1.000 & 1.000 & 1.000 \\
\hline 2-3 times/mo & $0.973(0.844-1.122)$ & $1.036(0.881-1.219)$ & $0.803(0.597-1.081)$ & $0.958(0.633-1.451)$ & $0.726(0.434-1.216)$ \\
\hline 1-2 times/wk & $0.925(0.758-1.129)$ & $0.860(0.675-1.096)$ & 1.095 (0.771-1.554) & $0.860(0.477-1.552)$ & $0.940(0.494-1.785)$ \\
\hline 3-4 times/wk & $1.111(0.740-1.668)$ & $1.181(0.739-1.888)$ & $0.945(0.419-2.132)$ & $1.860(0.755-4.578)$ & $1.360(1.122-1.412)$ \\
\hline Everyday & 1.494 (0.959-2.327) & $1.610(0.965-2.685)$ & $1.229(0.506-2.983)$ & $1.230(0.917-1.650)$ & $2.106(0.672-6.603)$ \\
\hline \multicolumn{6}{|l|}{ Smoking } \\
\hline None & 1.000 & 1.000 & 1.000 & 1.000 & 1.000 \\
\hline Ex-smoker & $1.293(0.919-1.821)$ & 1.276 (0.856-1.902) & 1.345 (0.692-2.613) & $0.631(0.156-2.551)$ & $1.099(0.350-3.456)$ \\
\hline Current smoker & $0.988(0.743-1.313)$ & $0.762(0.522-1.112)$ & $1.586(1.026-2.450)^{\star}$ & $1.115(0.520-2.390)$ & $0.172(0.024-1.234)$ \\
\hline \multicolumn{6}{|c|}{ Experience of colonoscopy } \\
\hline No & 1.000 & 1.000 & 1.000 & 1.000 & 1.000 \\
\hline Yes & $0.609(0.560-0.663)^{*}$ & $0.712(0.645-0.787)^{\star}$ & $0.406(0.346-0.475)^{*}$ & $0.312(0.246-0.397)^{\star}$ & $0.673(0.525-0.865)^{\star}$ \\
\hline
\end{tabular}

Values are presented as hazard ratio (95\% confidence interval).

$\mathrm{HR}$, hazard ratio; $\mathrm{Cl}$, confidence interval; DM, diabetes mellitus.

${ }^{*} \mathrm{P}<0.05$.

meat and vegetables, and vegetarians. Increased consumption of alcohol is also a risk factor for colorectal cancer. One report concluded that that consumption of more than $45 \mathrm{~g} /$ day of ethanol increases risk of colorectal cancer by $41 \%$ [39]. Our data only assessed frequency of alcohol consumption; in the future, the kind and amount of alcohol consumption should be included for more detailed analyses.

Many tools have been developed for colorectal screening. These screening tools decrease colorectal cancer death through early identification and removal of polyps [40]. Colonoscopy is widely used to screen for colorectal cancer in many countries. Colonoscopy is the gold standard for colorectal cancer screening. Colo- 
noscopy has high sensitivity and specificity, and simultaneous polypectomy is available during colonoscopy [41]. Even with normal findings, colonoscopy reduces the risk of colorectal cancer [42] and colorectal cancer-related death [43]. However, due to economic considerations and difficulties in bowel preparation, colonoscopy cannot always be used as a frequent screening tool. In many countries, colonoscopy for FOBT-positive individuals is widely used for colorectal cancer screening [44]. In our data, history of colonoscopy was a protective factor against colorectal cancer in both sexes. Routine use of colonoscopy reduces the incidence of colorectal cancer.

In this study, we identified a trend in colorectal cancer incidence in Korea over the past 10 years. The incidence substantially increased until 2012. We also analyzed risk factors of colorectal cancer in men and women. Because many factors are involved in the development of colorectal cancer, not all identified risk factors may be primary risk factors. However, this study analyzed risk factors for a large population in Korea. The National Health Examination data on lifestyle and eating habits are limited, and data that are more detailed may provide meaningful results about risk factors in the future.

\section{CONFLICT OF INTEREST}

No potential conflict of interest relevant to this article was reported.

\section{REFERENCES}

1. Torre LA, Bray F, Siegel RL, Ferlay J, Lortet-Tieulent J, Jemal A. Global cancer statistics, 2012. CA Cancer J Clin 2015;65:87-108.

2. Ferlay J, Steliarova-Foucher E, Lortet-Tieulent J, Rosso S, Coebergh JW, Comber H, et al. Cancer incidence and mortality patterns in Europe: estimates for 40 countries in 2012. Eur J Cancer 2013;49:1374-403.

3. Siegel R, Ward E, Brawley O, Jemal A. Cancer statistics, 2011: the impact of eliminating socioeconomic and racial disparities on premature cancer deaths. CA Cancer J Clin 2011;61:212-36.

4. Jung KW, Won YJ, Oh CM, Kong HJ, Lee DH, Lee KH. Prediction of cancer incidence and mortality in Korea, 2017. Cancer Res Treat 2017;49:306-12.

5. Alexander DD, Weed DL, Miller PE, Mohamed MA. Red meat and colorectal cancer: a quantitative update on the state of the epidemiologic science. J Am Coll Nutr 2015;34:521-43.

6. Liang PS, Chen TY, Giovannucci E. Cigarette smoking and colorectal cancer incidence and mortality: systematic review and meta-analysis. Int J Cancer 2009;124:2406-15.

7. Guraya SY. Association of type 2 diabetes mellitus and the risk of colorectal cancer: A meta-analysis and systematic review. World J Gastroenterol 2015;21:6026-31.

8. Azeem S, Gillani SW, Siddiqui A, Jandrajupalli SB, Poh V, Syed Sulaiman SA. Diet and colorectal cancer risk in asia--a systematic review. Asian Pac J Cancer Prev 2015;16:5389-96.

9. Sinha R, Doval DC, Hussain S, Kumar K, Singh S, Basir SF, et al. Lifestyle and sporadic colorectal cancer in India. Asian Pac J Cancer Prev 2015;16:7683-8.

10. Hubner J, Lewin P, Pritzkuleit R, Eisemann N, Maier W, Katalinic A. Colorectal cancer screening by colonoscopy and trends in disease-specific mortality: a population-based ecological study of 358 German districts. Int J Colorectal Dis 2019;34:599-605.

11. Niv Y, Sperber AD. Sensitivity, specificity, and predictive value of fecal occult blood testing (Hemoccult II) for colorectal neoplasia in symptomatic patients: a prospective study with total colonoscopy. Am J Gastroenterol 1995;90:1974-7.

12. Levin B, Lieberman DA, McFarland B, Smith RA, Brooks D, Andrews KS, et al. Screening and surveillance for the early detection of colorectal cancer and adenomatous polyps, 2008: a joint guideline from the American Cancer Society, the US Multi-Society Task Force on Colorectal Cancer, and the American College of Radiology. CA Cancer J Clin 2008;58:130-60.

13. Chen C, Stock C, Hoffmeister M, Brenner H. Public health impact of colonoscopy use on colorectal cancer mortality in Germany and the United States. Gastrointest Endosc 2018;87:213-21.e2.

14. Brenner H, Stock C, Hoffmeister M. Effect of screening sigmoidoscopy and screening colonoscopy on colorectal cancer incidence and mortality: systematic review and meta-analysis of randomised controlled trials and observational studies. BMJ 2014; 348:g2467.

15. Zauber AG, Winawer SJ, O'Brien MJ, Lansdorp-Vogelaar I, van Ballegooijen M, Hankey BF, et al. Colonoscopic polypectomy and long-term prevention of colorectal-cancer deaths. N Engl J Med 2012;366:687-96.

16. Singh H, Nugent Z, Demers AA, Kliewer EV, Mahmud SM, Bernstein $\mathrm{CN}$. The reduction in colorectal cancer mortality after colonoscopy varies by site of the cancer. Gastroenterology 2010;139: 1128-37.

17. Shin A, Jung KW, Woo H, Jeong SY. Colorectal cancer incidence in Korea is not the highest in the world. Cancer Res Treat 2016; 48:864-7.

18. Siegel RL, Fedewa SA, Anderson WF, Miller KD, Ma J, Rosenberg PS, et al. Colorectal cancer incidence patterns in the United States, 1974-2013. J Natl Cancer Inst 2017 Aug 1;109(8). doi: 10.1093/jnci/ djw322.

19. National Registry of Diseases Office. Cancer Survival in Singapore 1973-2012 [Internet]. Singapore: National Registry of Diseases Office; 2015 [cited 2019 Apr 14]. Available from: https://www.nrdo. gov.sg/publications/cancer?AspxAutoDetectCookieSupport=1.

20. Organization for Economic Cooperation and Development (OECD). Meat consumption (indicator) [Internet]. Pari: OCCD; 2019 [cited 2019 Jan 12]. Available from: https://www.oecd-ilibrary. org/agriculture-and-food/meat-consumption/indicator/english_ fa290fd0-en.

21. Bultman SJ. Emerging roles of the microbiome in cancer. Carcinogenesis 2014;35:249-55. 
22. David LA, Maurice CF, Carmody RN, Gootenberg DB, Button JE, Wolfe BE, et al. Diet rapidly and reproducibly alters the human gut microbiome. Nature 2014;505:559-63.

23. Bingham SA, Day NE, Luben R, Ferrari P, Slimani N, Norat T, et al. Dietary fibre in food and protection against colorectal cancer in the European Prospective Investigation into Cancer and Nutrition (EPIC): an observational study. Lancet 2003;361:1496-501.

24. Rao YK, Fang SH, Tzeng YM. Synthesis and biological evaluation of 3',4'5'-trimethoxychalcone analogues as inhibitors of nitric oxide production and tumor cell proliferation. Bioorg Med Chem 2009; 17:7909-14.

25. Huxley RR, Ansary-Moghaddam A, Clifton P, Czernichow S, Parr CL, Woodward M. The impact of dietary and lifestyle risk factors on risk of colorectal cancer: a quantitative overview of the epidemiological evidence. Int J Cancer 2009;125:171-80.

26. Schlesinger S, Lieb W, Koch M, Fedirko V, Dahm CC, Pischon T, et al. Body weight gain and risk of colorectal cancer: a systematic review and meta-analysis of observational studies. Obes Rev 2015; 16:607-19.

27. Karahalios A, English DR, Simpson JA. Weight change and risk of colorectal cancer: a systematic review and meta-analysis. Am J Epidemiol 2015;181:832-45.

28. Shin CM, Han K, Lee DH, Choi YJ, Kim N, Park YS, et al. Association among obesity, metabolic health, and the risk for colorectal cancer in the general population in Korea using the National Health Insurance Service-National Sample Cohort. Dis Colon Rectum 2017;60:1192-200.

29. Butterworth AS, Higgins JP, Pharoah P. Relative and absolute risk of colorectal cancer for individuals with a family history: a metaanalysis. Eur J Cancer 2006;42:216-27.

30. Jung YS, Kim NH, Yang HJ, Park SK, Park JH, Park DI, et al. Family history of gastric cancer is associated with the risk of colorectal neoplasia in Korean population. Dig Liver Dis 2017;49: 1155-61.

31. Beebe-Dimmer JL, Yee C, Paskett E, Schwartz AG, Lane D, Palmer NRA, et al. Family history of prostate and colorectal cancer and risk of colorectal cancer in the Women's health initiative. BMC Cancer 2017;17:848.

32. Goldbohm RA, van den Brandt PA, van 't Veer P, Brants HA, Dorant E, Sturmans F, et al. A prospective cohort study on the re- lation between meat consumption and the risk of colon cancer. Cancer Res 1994;54:718-23.

33. Gerhardsson de Verdier M, Hagman U, Peters RK, Steineck G, Overvik E. Meat, cooking methods and colorectal cancer: a casereferent study in Stockholm. Int J Cancer 1991;49:520-5.

34. Cross AJ, Ferrucci LM, Risch A, Graubard BI, Ward MH, Park Y, et al. A large prospective study of meat consumption and colorectal cancer risk: an investigation of potential mechanisms underlying this association. Cancer Res 2010;70:2406-14.

35. Alexander DD, Miller AJ, Cushing CA, Lowe KA. Processed meat and colorectal cancer: a quantitative review of prospective epidemiologic studies. Eur J Cancer Prev 2010;19:328-41.

36. Birt DF. The influence of dietary fat on carcinogenesis: lessons from experimental models. Nutr Rev 1990;48:1-5.

37. Trock B, Lanza E, Greenwald P. Dietary fiber, vegetables, and colon cancer: critical review and meta-analyses of the epidemiologic evidence. J Natl Cancer Inst 1990;82:650-61.

38. Fung KY, Ooi CC, Zucker MH, Lockett T, Williams DB, Cosgrove LJ, et al. Colorectal carcinogenesis: a cellular response to sustained risk environment. Int J Mol Sci 2013;14:13525-41.

39. Cho E, Smith-Warner SA, Ritz J, van den Brandt PA, Colditz GA, Folsom AR, et al. Alcohol intake and colorectal cancer: a pooled analysis of 8 cohort studies. Ann Intern Med 2004;140:603-13.

40. Winawer SJ. The history of colorectal cancer screening: a personal perspective. Dig Dis Sci 2015;60:596-608.

41. Bray C, Bell LN, Liang H, Collins D, Yale SH. Colorectal cancer screening. WMJ 2017;116:27-33.

42. Lee JK, Jensen CD, Levin TR, Zauber AG, Schottinger JE, Quinn $\mathrm{VP}$, et al. Long-term risk of colorectal cancer and related deaths after a colonoscopy with normal findings. JAMA Intern Med 2019; 179:153-60.

43. Samadder NJ, Curtin K, Pappas L, Boucher K, Mineau GP, Smith $\mathrm{K}$, et al. Risk of incident colorectal cancer and death after colonoscopy: a population-based study in Utah. Clin Gastroenterol Hepatol 2016;14:279-86.e1-2.

44. Mandel JS, Bond JH, Church TR, Snover DC, Bradley GM, Schuman LM, et al. Reducing mortality from colorectal cancer by screening for fecal occult blood. Minnesota Colon Cancer Control Study. N Engl J Med 1993;328:1365-71. 